\title{
Structural characterization of liquid phase sintered silicon carbide by high-resolution X-ray diffractometry
}

\section{(Caracterização estrutural do carbeto de silício sinterizado na presença de fase líquida por difratometria de raios $X$ de alta resolução)}

\author{
C. A. Kelly ${ }^{1}$, P. A. Suzuki ${ }^{1}$, S. Ribeiro ${ }^{1}$, S. Kycia ${ }^{2,3}$ \\ ${ }^{1}$ FAENQUIL - DEMAR, Lorena, C.P. 116, SP, Brasil 12600-970 \\ ${ }^{2}$ Laboratório Nacional de Luz Síncrotron - LNLS, Campinas, SP, Brasil \\ ${ }^{3}$ Physics Department, University of Gwelph, Gwelph, Canada \\ tel.: OXX-12-3159.9916; fax: OXX-12-3153.3006 \\ psuzuki@demar.faenquil.br
}

\begin{abstract}
Silicon carbide $(\mathrm{SiC})$ was sintered using two different additives: AlN- $\mathrm{Y}_{2} \mathrm{O}_{3}$ or AlN-CRE $\mathrm{O}_{3}$. $\mathrm{CRE}_{2} \mathrm{O}_{3}$ is a mixed oxide formed by $\mathrm{Y}_{2} \mathrm{O}_{3}$ and rare-earth oxides. The crystalline structures of the phases were analyzed by high-resolution X-ray diffraction using synchrotron light source. The results of the Rietveld refinement of the mixed oxide show a solid solution formation. In both silicon carbide samples prepared using AlN- $\mathrm{Y}_{2} \mathrm{O}_{3}$ or $\mathrm{AlN}-\mathrm{CRE}_{2} \mathrm{O}_{3} 3 \mathrm{C}(\beta$-phase) and $6 \mathrm{H}$ ( $\alpha$-phase) polytypes were found. The structural and microstructural results for both samples were similar. This is an indication of the viability of the use of $\mathrm{CRE}_{2} \mathrm{O}_{3}$ in substitution for $\mathrm{Y}_{2} \mathrm{O}_{3}$ as additive to obtain dense materials.
\end{abstract}

Keywords: $\mathrm{SiC}$, liquid phase, X-ray diffraction, synchrotron, Rietveld method.

\section{Resumo}

\begin{abstract}
Amostras de carbeto de silício ( $\mathrm{SiC}$ ) foram sinterizadas com dois aditivos: $\mathrm{AlN}-\mathrm{Y}_{2} \mathrm{O}_{3}$ ou AlN-CRE $\mathrm{O}_{3}$. $\mathrm{CRE}_{2} \mathrm{O}_{3}$ é um óxido misto formado por $\mathrm{Y}_{2} \mathrm{O}_{3}$ e óxidos de terras raras. A estrutura cristalina das fases nas amostras foi analisada através de difração de raios $X$ de alta resolução com fonte de luz síncrotron. Os resultados de refinamento do óxido misto pelo método de Rietveld mostraram a formação de uma solução sólida. Em ambas as amostras preparadas usando $\mathrm{AlN}-\mathrm{Y}_{2} \mathrm{O}_{3}$ ou AlN- $\mathrm{CRE}_{2} \mathrm{O}_{3}$ foram detectados politipos $3 C$ (fase $\beta$ ) e $6 H$ (fase $\alpha$ ). Os resultados estruturais e microestruturais das duas amostras mostraram-se similares. Esta é uma indicação da viabilidade do uso de $\mathrm{CRE}_{2} \mathrm{O}_{3}$ em substituição a $\mathrm{Y}_{2} \mathrm{O}_{3}$ como aditivo para a obtenção de materiais cerâmicos densos. Palavras-chave: $\mathrm{SiC}$, fase líquida, difração de raios $X$, síncrotron, método de Rietveld.
\end{abstract}

\section{INTRODUCTION}

Silicon carbide (SiC) shows excellent properties for structural applications. However, the production of highdensity ceramics by solid state sintering is difficult [1] due to the strong covalent character of the bonds and low selfdiffusion coefficient. Therefore, dense $\mathrm{SiC}$ ceramics can be commonly obtained by liquid-phase sintering, by use of additives such as: $\mathrm{Al}_{2} \mathrm{O}_{3}$ and/or $\mathrm{Y}_{2} \mathrm{O}_{3}$ [2-4]. The liquidphase sintered silicon carbide have shown higher fracture toughness in comparison to that produced from solid-state sintered ceramics [5]. An alternative additive for sintering silicon carbide is the mixed oxide $\left(\mathrm{CRE}_{2} \mathrm{O}_{3}\right)$ formed by a mixture of yttrium oxide and rare-earth oxides. This mixed oxide could be produced from the mineral xenotime, using a method described in a previous work [6]. It was successfully used for the liquid-phase sintering of $\mathrm{Si}_{3} \mathrm{~N}_{4}$ [7]. The main advantage for the use of the mixed oxide as additive is the lower cost when compared to the pure $\mathrm{Y}_{2} \mathrm{O}_{3}[6]$. On the other hand, the main question that arises about the use of the mixed oxide as additive is about its properties when compared to that sintered using pure $\mathrm{Y}_{2} \mathrm{O}_{3}$.

The structure of the silicon carbide is known to be complex. More than 180 different polytypes are known [8] The most common polytypes are 3C (cubic), 4H (hexagonal), $6 \mathrm{H}$ (hexagonal) and 15R (rhombohedral). The 3C polytype, also called $\beta$-SiC phase, is stable at lower temperatures (below $2000{ }^{\circ} \mathrm{C}$ ) [8-10] showing globular grains with low fracture toughness and high hardness. The $\alpha$-SiC phase that include all polytypes presenting hexagonal or rhombohedral symmetries is stable at higher temperatures, above $2000{ }^{\circ} \mathrm{C}$. This phase shows elongated grains with high fracture toughness and low hardness. A homogeneous microstructure is commonly hard to be obtained. For structural applications, it has been proposed a microstructure formed by elongated plate-like grains obtained during the $\beta-\alpha$ transformation, due to the higher fracture toughness [11].

$\mathrm{X}$-ray diffraction is a suitable technique for the identification of the polytypes. The main difficulty in the analysis of the diffraction patterns is the overlap of several 
Bragg reflections, since the basal lattice parameter $a=3.08 \_\AA$ is close for all polytypes. Another way to perform a detailed investigation of the structure and microstructure is the use of high-resolution X-ray diffraction with synchrotron radiation source. By this technique, some overlapped reflections could be resolved and small amount of secondary phases could be detected due to the excellent signal-noise ratio. The refinement of the structural parameters could be performed using a whole-pattern refinement method, as the Rietveld method.

Thus, the aim of this work was the investigation of the structure and microstructure of the silicon carbide sintered by: yttrium oxide and aluminum nitride (AlN) or mixed oxide and aluminum nitride as additives. The characterization of the samples was done using techniques, such as high resolution X-ray diffractometry (HRXRD) and Scanning Electron Microscopy (SEM). The refinements of the structures were done using the Rietveld method.

\section{EXPERIMENTAL}

Commercially available silicon carbide (H. C. Starck - grade BF 12) was sintered using different additives: yttria $\left(\mathrm{Y}_{2} \mathrm{O}_{3}\right)$ and AlN (H. C. Starck - fine grade) or mixed oxide $\left(\mathrm{CRE}_{2} \mathrm{O}_{3}\right)$ and AlN (H C. Starck - fine grade). The mixed oxide formed by a mixture of yttrium oxide and rare--earth oxide was produced from xenotime mineral using a method developed at DEMAR-FAENQUIL and described elsewhere [6]. The composition of the mixed oxide formed by yttrium and rare-earth oxide obtained by chemical analysis is listed in Table I. The molar proportion used for AlN and $\mathrm{Y}_{2} \mathrm{O}_{3}$ was 3:2 [12]. The same molar proportion was used for AlN and mixed oxide. The samples containing $\mathrm{AlN}-\mathrm{Y}_{2} \mathrm{O}_{3}(\mathrm{Y} 10)$ and AlN-mixed oxide (M10) as additives were mixed using isopropyl alcohol and milled by attrition using $\mathrm{Si}_{3} \mathrm{~N}_{4}$ balls for $4 \mathrm{~h}$. After mixing, the powders were dried in a vacuum evaporator at $80_{-}^{\circ} \mathrm{C}$ for $24 \mathrm{~h}$. The powder batches $(100 \mathrm{~g})$ of containing $10 \mathrm{vol}-\%$ of additive were mixed with isopropyl alcohol and milled for 10_h in the attrition mill. The overall compositions of the powder batches are listed in Table II.

The powders were pressed at $300 \mathrm{MPa}$ in cold isostatic

Table I - Composition of the mixed oxide formed by the mixture of yttrium oxide and rare-earth oxides.

[Tabela I - Composição do óxido misto formado pela mistura de óxido de ítrio e óxidos de terras raras.]

\begin{tabular}{cccc}
\hline oxide & wt. \% & oxide & wt. \% \\
\hline $\mathrm{Y}_{2} \mathrm{O}_{3}$ & 44.60 & $\mathrm{Gd}_{2} \mathrm{O}_{3}$ & 1.17 \\
$\mathrm{Yb}_{3} \mathrm{O}_{3}$ & 19.71 & $\mathrm{~Tb}_{2} \mathrm{O}_{3}$ & 0.82 \\
$\mathrm{Er}_{2} \mathrm{O}_{3}$ & 13.94 & $\mathrm{Sm}_{2} \mathrm{O}_{3}$ & 0.38 \\
$\mathrm{Dy}_{2} \mathrm{O}_{3}$ & 10.25 & $\mathrm{Ce}_{2} \mathrm{O}_{3}$ & 0.09 \\
$\mathrm{Ho}_{2} \mathrm{O}_{3}$ & 3.27 & $\mathrm{Eu}_{2} \mathrm{O}_{3}$ & 0.02 \\
$\mathrm{Tm}_{2} \mathrm{O}_{3}$ & 2.83 & $\mathrm{Nd}_{2} \mathrm{O}_{3}$ & 0.12 \\
$\mathrm{Lu}_{2} \mathrm{O}_{3}$ & 2.62 & $\mathrm{La}_{2} \mathrm{O}_{3}$ & 0.01 \\
\hline
\end{tabular}

Table II - Composition of the prepared samples. [Tabela II - Composição das amostras preparadas.]

\begin{tabular}{|c|c|c|c|c|c|}
\hline \multirow[b]{2}{*}{ Sample } & \multirow[b]{2}{*}{$\begin{array}{l}\text { Additive } \\
\text { (\% vol.) }\end{array}$} & \multicolumn{4}{|c|}{ Composition (wt. \%) } \\
\hline & & $\overline{\beta-S i C}$ & AlN & $\mathrm{Y}_{2} \mathrm{O}_{3}$ & $\begin{array}{l}\text { mixed } \\
\text { oxide }\end{array}$ \\
\hline $\begin{array}{l}\mathrm{Y} 10 \\
\end{array}$ & 10 & 85.88 & 1.52 & 12.60 & - \\
\hline M10 & 83.05 & 1.83 & - & 15.12 & \\
\hline
\end{tabular}

condition to obtain cylindrical shape samples of $15 \mathrm{~mm}$ diameter and $8 \mathrm{~mm}$ height. The green relative densities for Y10 and M10 samples were respectively $55.2(6) \%$ and $56.1(9) \%$. Sintering was performed in a graphite heating element furnace (Thermal Technology, model 1000-4560-FP-20). The samples were inserted in a graphite crucible. The powder bed was composed by $70 \% \mathrm{SiC}$ and $30 \%$ of the powder mixture of each composition studied. The furnace was programmed to heat-up to $2000{ }^{\circ} \mathrm{C}$ at a $20{ }^{\circ} \mathrm{C} / \mathrm{min}$ rate, holding at this temperature for $1 \mathrm{~h}$ in $0,1 \mathrm{MPa}$ argon atmosphere. Then, it was cooled down to the room temperature at a $20^{\circ} \mathrm{C} / \mathrm{min}$ rate.

The weight loss during the sintering process was calculated by the difference between the weight of each sample prior and after sintering. Bulk density was measured by the immersion method in distilled water, according to the Archimedes principle.

High-resolution X-ray powder diffraction measurements were performed at Brazilian Synchrotron Light Source - LNLS using XRD1-D12A beam line. Multi-axis Hubber diffractometer mounted in a concentric coupled two circle configuration $(\omega-2 \theta)$ was used. The measurements were carried out using the monochromatic $10 \mathrm{keV}(\lambda=1.2398 \AA)$ energy beam. The sintered samples were ground in a stainless steel mortar. The powder was passed through $20 \mu \mathrm{m}$ sieve. This powder was pulverized over the cylindrical holder (10 $\mathrm{mm}$ diameter and $2 \mathrm{~mm}$ depth) that was kept in planar rotation in order to randomize the particle distribution that contributes to the Bragg reflection. The diffracted beam was collected using a (200) germanium analyzer crystal and the scintillation detector combination.

The refinement of the crystal structure was performed by the_Rietveld method using the_FullProf program [13] and the crystallographic data reported in the literature $[14,15]$.

The microstructural characterization was performed on ground, polished and chemically etched samples with distilled water, oxygen peroxide, ammonium hydroxide, liquid soap and colloidal silica mixture, for $15 \mathrm{~min}$ at room temperature. The polishing and chemical etching of the samples were performed in an automatic mandrel, Igan Wurtz, model Phoenix 4000. The micrographs of the etched samples were obtained in a LEO-Zeiss 1450 VP Scanning Electron Microscope with $20 \mathrm{kV}$ electron energy and using secondary electron detector.

\section{RESULTS AND DISCUSSION}

Powders of yttria and mixed oxide were analyzed by 
high-resolution X-ray diffraction. The results of the Rietveld refinement are shown in the_Fig. 1. The structure of the mixed oxide was refined taking into account the crystallographic data of $\mathrm{Y}_{2} \mathrm{O}_{3}$-type structure [14]. The peaks of yttria were sharp, with full-width-at-half-maximum (FWHM) about 0.04 deg for the most intense (222) peak. The peaks of the mixed oxide are small and broader, presenting 0.50 deg for the most intense (222) peak. In comparison, the breadth of the mixed oxide reflections is more than ten times larger than that of the pure yttria. The intensity of the most intense (222) peak of the mixed oxide is approximately 8 times smaller than that of the pure yttria. However, all peaks of the mixed oxide were well-defined, in a clear evidence of a true solid solution formation. The refined lattice parameter for the

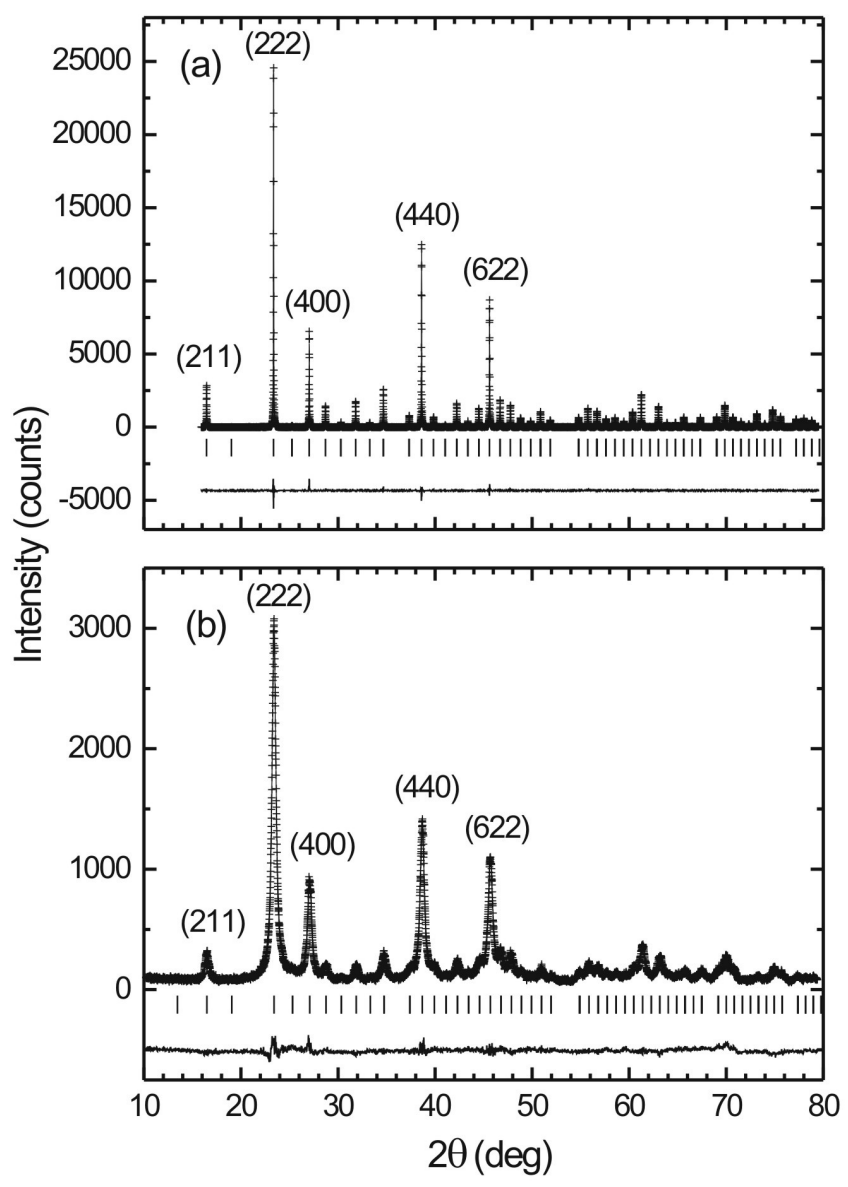

Figure 1: Rietveld refinement of: (a) $\mathrm{Y}_{2} \mathrm{O}_{3}$ and (b) mixed oxide. The $(+)$ marks show the measured data and the line the calculated pattern. The vertical bars show positions of the Bragg reflections. Only the highest intensity peaks are indexed by Miller indexes. The continuous line below the bars shows the difference between calculated and measured data.

[Figura 1: Resultados de refinamento pelo método de Rietveld de: (a) $\mathrm{Y}_{2} \mathrm{O}_{3}$ e (b) óxido misto. O símbolo (+) representa os dados medidos e a linha contínua o difratograma calculado. As barras verticais indicam as posições das reflexões de Bragg. Apenas os picos mais intensos estão indexados pelos índices de Miller. A linha contínua abaixo das barras mostra a diferença entre os dados medidos e calculados.] mixed oxide $\left(\mathrm{a}=10.588(1) \_\AA\right.$ ) was smaller than that of the pure yttria ( $a=10.6080(5) \_\AA$ ), attributed to the smaller mean atomic radius.

Samples of silicon carbide were sintered using different additives: $\mathrm{Y}_{2} \mathrm{O}_{3}$ and $\mathrm{AlN}$ or $\mathrm{CRE}_{2} \mathrm{O}_{3}$ and $\mathrm{AlN}$. The relative densities for the both samples were achieved to be $98-\%$ and the weight losses were lower than 5-\%.

High-resolution X-ray diffractometry was performed in a sample of silicon carbide sintered using $\mathrm{Y}_{2} \mathrm{O}_{3}$ and AlN as additive. Sharp and intense peaks were observed. It is easy to note the excellent signal-noise ratio of the diffraction

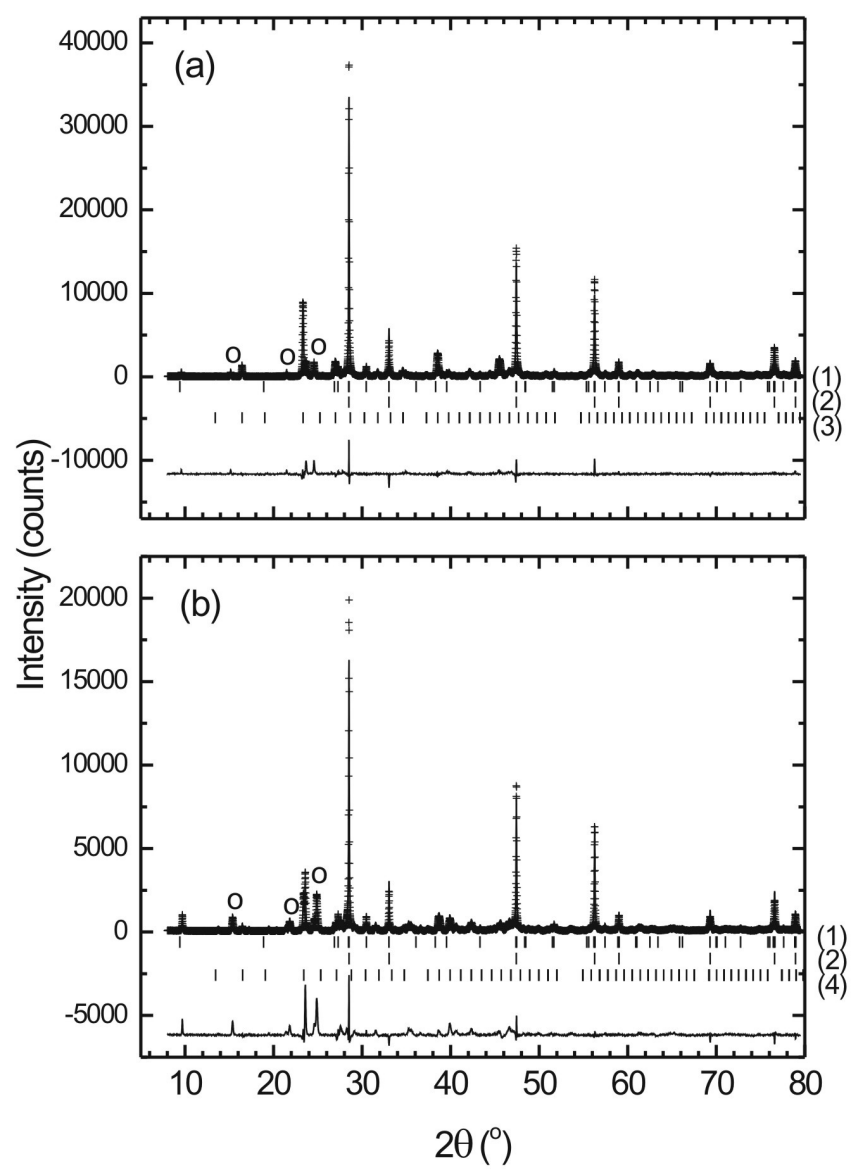

Figure 2: Rietveld refinement of the silicon carbide sintered using: (a) $\mathrm{Y}_{2} \mathrm{O}_{3}$ and AlN and (b) mixed oxide and AlN as additive. The (+) marks show the measured data and the line the calculated pattern. The vertical bars show positions of the Bragg reflections. The refined phases were: (1) $\alpha$-SiC (6H), (2) $\beta$-SiC (3C), (3) $\mathrm{Y}_{2} \mathrm{O}_{3}$ and (4) the mixed oxide. The (o) symbol refers to $\mathrm{Al}_{2} \mathrm{Y}_{4} \mathrm{O}_{9}$ phase. The continuous line below the bars shows the difference between calculated and measured data.

[Figura 2: Resultados de refinamento pelo método de Rietveld de carbeto de silício sinterizado utilizando: (a) $\mathrm{Y}_{2} \mathrm{O}_{3}$ e AlN ou (b) óxido misto e AlN como aditivos. $O$ símbolo $(+)$ representa os dados medidos e a linha contínua o difratograma calculado. As barras verticais indicam as posições das reflexões de Bragg. As fases refinadas foram: (1) $\alpha$-SiC (6H), (2) $\beta$-SiC (3C), (3) $\mathrm{Y}_{2} \mathrm{O}_{3} e$ (4) óxido misto. $O$ símbolo (o) indica a presença das reflexões da fase $\mathrm{Al}_{2} \mathrm{Y}_{4} \mathrm{O}_{9}$. A linha contínua abaixo das barras mostra a diferença entre os dados medidos e calculados.] 
Table III - Refined lattice parameter(s) and fractions of the phases appearing in the samples Y10 and M10. The $\alpha-S i C$ crystallizes in a hexagonal structure, while the $\beta-\mathrm{SiC}, \mathrm{Y}_{2} \mathrm{O}_{3}$ and the mixed oxide crystallize in a cubic structure.

[Tabela III - Parâmetro(s) de rede e proporção das fases presentes nas amostras Y10 e M10. A fase $\alpha$-SiC cristaliza em uma estrutura hexagonal, enquanto as fases $\beta-\mathrm{SiC}, \mathrm{Y}_{2} \mathrm{O}_{3}$ e o óxido misto cristalizam em estruturas cúbicas.]

\begin{tabular}{|c|c|c|}
\hline & \multicolumn{2}{|c|}{ sample } \\
\hline & $\overline{\mathrm{Y} 10}$ & M10 \\
\hline \multicolumn{3}{|l|}{ Phase 1: $\alpha-\operatorname{SiC}(6 \mathrm{H})$} \\
\hline Phase fraction (wt. \%) & $12.4(3)$ & $23(1)$ \\
\hline Lattice parameter a $(\AA)$ & $3.082(1)$ & $3.082(3)$ \\
\hline$c(\AA)$ & $15.12(1)$ & $15.13(2)$ \\
\hline \multicolumn{3}{|l|}{ Phase 2: $\beta$-SiC (3 C) } \\
\hline Phase fraction (wt. \%) & $70.6(5)$ & $65(1)$ \\
\hline Lattice parameter a $(\AA)$ & $4.3610(2)$ & $4.3605(3)$ \\
\hline \multicolumn{3}{|c|}{ Phase 3: $\mathrm{Y}_{2} \mathrm{O}_{3}$ or mixed oxide } \\
\hline Phase fraction (wt. \%) & 17.1(1) & $11.6(3)$ \\
\hline Lattice parameter a $(\AA)$ & $10.625(1)$ & $10.584(6)$ \\
\hline
\end{tabular}
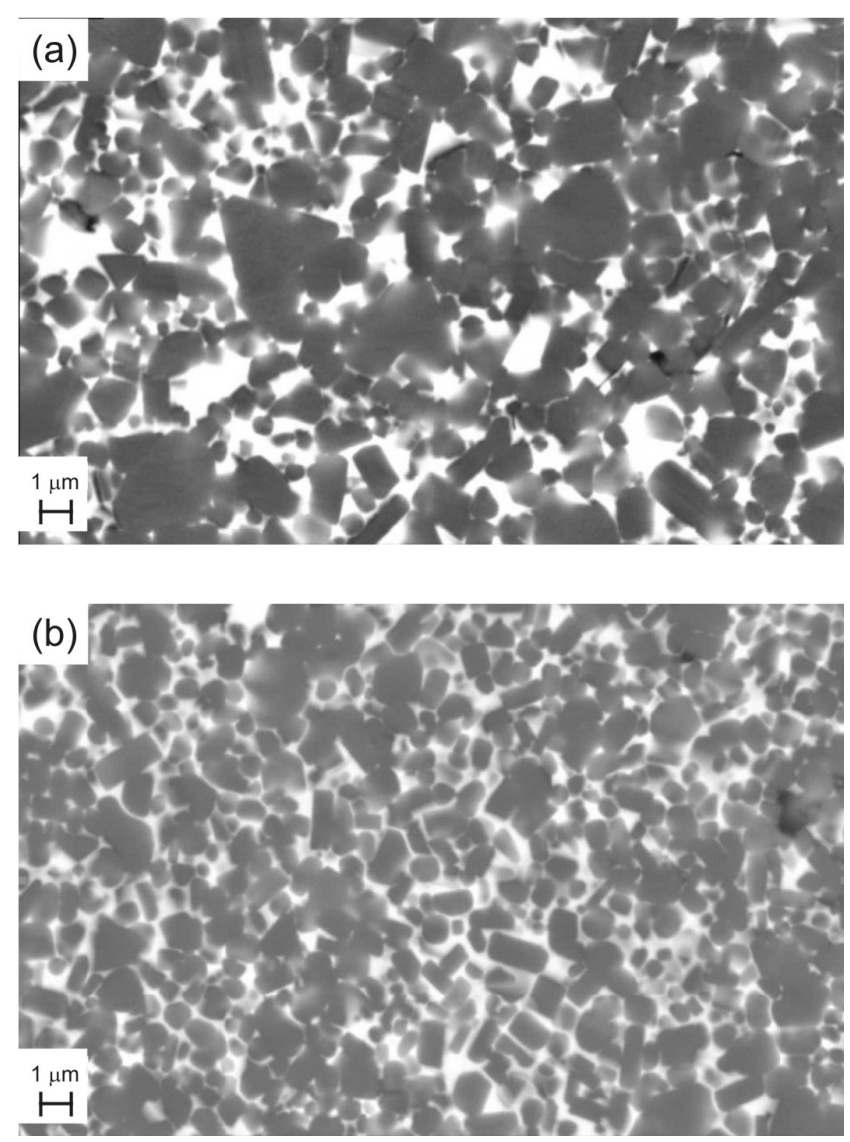

Figure 3: Scanning electron microscopy micrographs of: (a) Y10 and (b) M10 samples sintered at $2000{ }^{\circ} \mathrm{C}$ for $1 \mathrm{~h}$ under $0.1 \mathrm{MPa}$ argon atmosphere.

[Figura 3: Micrografias obtidas por microscopia eletrônica de varredura das amostras: (a) Y10 e (b) M10 sinterizadas a $2000^{\circ} \mathrm{C}$ por $1 \mathrm{~h}$ sob atmosfera de argônio de 0,1MPa.] patterns. The result of the Rietveld refinement is shown in the Fig. 2(a). The peaks presenting intensities as low as $1 \%$ could be indexed. The following phases were identified: $\alpha$ $\mathrm{SiC}(6 \mathrm{H}), \beta-\mathrm{SiC}(3 \mathrm{C}), \mathrm{Y}_{2} \mathrm{O}_{3}$ and $\mathrm{Al}_{2} \mathrm{Y}_{4} \mathrm{O}_{9}$. No peaks belonging to $\mathrm{SiC}(4 \mathrm{H})$ and $\mathrm{SiC}(21 \mathrm{R})$ were found. Although the FWHM of the peaks was smaller, around $0.08 \mathrm{deg}$ for the most intense peak, the overlapped reflections of $\alpha-\mathrm{SiC}(6 \mathrm{H})$ and $\beta$ $\mathrm{SiC}(3 \mathrm{C})$ were unresolved. This result shows the proximity of the lattice parameters of $\alpha-\operatorname{SiC}(6 \mathrm{H})$ and $\beta-\mathrm{SiC}(3 \mathrm{C})$ phases.

The X-ray diffraction pattern of the sample of silicon carbide sintered using mixed oxide and AlN as additive is similar to that of the $\mathrm{SiC}$ sintered using pure $\mathrm{Y}_{2} \mathrm{O}_{3}$ and AlN. The peaks are sharp and well-defined. The FWHM of the most intense peak was also similar for the both samples, being around $0.08 \mathrm{deg}$. Fig. 2(b) shows the result of the refinement taking account three phases: $\alpha$-SiC $(6 \mathrm{H})$, $\beta$-SiC (3C) and mixed oxide with $\mathrm{Y}_{2} \mathrm{O}_{3}$-type structure.

The refined structural parameters are shown in Table III. The lattice parameters of $\alpha-\mathrm{SiC}(6 \mathrm{H})$ and $\beta-\mathrm{SiC}(3 \mathrm{C})$ of the samples sintered using $\mathrm{AlN}-\mathrm{Y}_{2} \mathrm{O}_{3}$ or $\mathrm{AlN}$-mixed oxide were close. The proportion of $\alpha-\operatorname{SiC}(6 \mathrm{H})$ phase in M10 sample was found slightly higher than that of Y10 sample.

The micrographs of the sintered samples are shown in Fig. 3. Two different regions can be observed: $\mathrm{SiC}$ phase (gray area) and intergranular phase (white area). Grains of silicon carbide presenting plate-like shape with low aspect ratio indicate an incomplete $\beta$ to $\alpha$-SiC transformation during the sintering step. The microstructure of the Y10 sample shows a heterogeneous distribution of the grains, while the M10 sample presents more homogeneous and fine microstructure. For the microstructural point of view, the silicon carbide prepared from AlN-mixed oxide as additive shows a better result.

The HRXRD and SEM show similarities in both sintered samples, e.g. concerning to the intergranular phases, proportion of $\beta-\alpha$ phases and the microstructures. The results of the sintering properties, as densification and weight loss were also similar. These results show that the use of mixed oxide as additive is appropriate for sintering silicon carbide at lower cost in comparison to $\mathrm{Y}_{2} \mathrm{O}_{3}$. Further investigations focused on the mechanical properties, such as hardness and fracture toughness for these samples are considered.

\section{CONCLUSIONS}

Samples of silicon carbide sintered using $\mathrm{AlN}-\mathrm{Y}_{2} \mathrm{O}_{3}$ or AlN-mixed oxide were investigated by means of high-resolution X-ray diffraction and scanning electron microscopy. The results of the silicon carbide sintered using AlN-mixed oxide show structural and morphological properties similar to that prepared with $\mathrm{AlN}-\mathrm{Y}_{2} \mathrm{O}_{3}$. This is an indication that high-density silicon carbide could be produced by using mixed oxide as additive at lower cost.

\section{ACKNOWLEDGEMENTS}

The authors would like to acknowledge $\mathrm{CNPq}$ and 
CAPES for financial support. This work was partially supported by the Brazilian Synchrotron Light Source (LNLS) under proposal D12A-XRD1-2047/03.

\section{REFERENCES}

[1] D. Bloor, R. J. Flemings, S. Mahajan, The Encyclopedia of Advanced Materials, 4 (1994) 2455.

[2] J. H. She, K. Ueno, Mater. Res. Bull. 34, 10-11 (1999) 1629.

[3] Y. -IL Lee, Y. -W. Kim, J. Mater. Sci. 36 (2001) 699.

[4] V. Izhevskyi, L. A. Genova, A. H. A. Bressiani, J. C. Bressiani, Mater. Res. 3, 4 (2000) 131.

[5] N. P. Padture, J. Am. Ceram. Soc. 77, 2 (1994) 519.

[6] S. Ribeiro, PhD. thesis, Demar-Faenquil, Lorena, SP, Brasil (1997) in portuguese.

[7] C. Santos, K. Strecker, S. Ribeiro, J. V. C. Souza, O. M. M. Silva, C. R. M. Silva, Mater. Lett. 58 (2004) 1792.

[8] L. K. Frevel, D. R. Petersen, C. K. Saha, J. Mater. Sci. 27 (1992) 1913.
[9] Y. Inomata, in Silicon Carbide Ceramics - 1. Fundaments and Solid Reaction, ed. S. Somiya, Y. Inomata, Elsevier Appl. Sci., London and New York (1991) 11.

[10] N. W. Jeeps, T. F. Page, Crystal Growth and Characterization of Polytype Structures 7 (1983) 259.

[11] S. S. Shinozaki, J. Hangas, K. R. Carduner, M. J. Rokosz, K. Suzuki, N. Shinohara, J. Mater. Res. 8, 7 (1993) 1635.

[12] A. L. Ortiz, F. L. Cubrera, F. Sanchez-Bajo, F. Guiberteau, H. W. Xu, N. P. Padture, J. Am. Ceram. Soc. 83, 9 (2000) 2282.

[13] J. Rodriguez-Carvajal, An introduction to the program FullProf 2000 (version July 2001), Laboratoire Leon Brillouin, CEA-CNRS, Saclay, France (2001).

[14] R. W. G. Wyckoff, Crystal structures, Interscience Publishers (1965).

[15] P. Villars, L. D. Calvert (ed.), Pearson's Handbook of Crystallographic Data for Intermetallic Phases, $2^{\text {nd }}$ ed., ASM International, Materials Park, OH (1991). (Rec. 28/06/2004, Rev. 02/05/2005, Ac. 27/05/2005) 